\title{
Evli Kadınların Aile Planlaması Tutum ve Niyetleri Arasındaki İlişkinin Belirlenmesi
}

\author{
The Determination of Relationship between Family Planning Attitudes and \\ Intentions of Married Women
}

\author{
Sibel Ejder Tekgündüz ${ }^{1}$, Elif Yağmur Gür², Serap Ejder Apay ${ }^{2}$ \\ ${ }^{1}$ Erzurum Şehir Hastanesi, Erzurum, Türkiye \\ ${ }^{2}$ Atatürk Üniversitesi Sağlık Bilimleri Fakültesi, Ebelik Bölümü, Erzurum, Türkiye \\ Yazışma Adresi / Correspondence: \\ Elif Yağmur Gür \\ Atatürk Üniversitesi Sağllk Bilimleri Fakültesi Ebelik Bölümü 25240, Yakutiye/ ERZURUM \\ T: +90507 1293049 E-mail : yagmur_8707@hotmail.com / yagmur.ozorhan@atauni.edu.tr \\ Geliş Tarihi / Received : 05.01.2021 Kabul Tarihi / Accepte: 04.12.2021 \\ Orcid : \\ Sibel Tekgündüz https://orcid.org/0000-0002-0992-1944 \\ Elif Yağmur Gür https://orcid.org/0000-0002-4949-3614 \\ Serap Ejder Apay https://orcid.org/0000-0003-0978-1993 \\ ( Sakarya Tip Dergisi / Sakarya Med J 2021, 11(4):743-750 ) DOI: 10.31832/smj.854295
}

\footnotetext{
$\ddot{\mathrm{Oz}}$

Amaç Bu çalışma kadınların aile planlamasına ilişkin tutumları ve niyetleri arasındaki ilişkinin belirlenmesi amacıyla yapılmıștır.

Yöntem ve Kesitsel ve tanımlayıcı nitelikte yapılan araştırma Ekim-Aralık 2020 tarihleri arasında doğuda bir devlet hastanesinde kadın doğum polikliniklerine başvuran evli kadınlar

Gereçler üzerinde yapılmıștır. Araștırmada örneklem seçimine gidilmeden araștırmaya katılmaya gönüllü olan tüm kadınlar araștırma kapsamına alınmıștır. Verilerin toplanmasında tanıtıcı bilgi formu, Aile Planlaması Tutum Ölçeği ve Aile Planlaması Niyet Ölçeği kullanılmıștır. Veriler kadınlara poliklinik hizmetleri sonrası anketörler tarafından yüz yüze görüşme tekniği ile hastanedeki boș bir odada toplanmıștır. Verilerin değerlendirilmesinde sayı, yüzde, ortalama, standart sapma, Pearson korelasyon analizi kullanılmıștır.

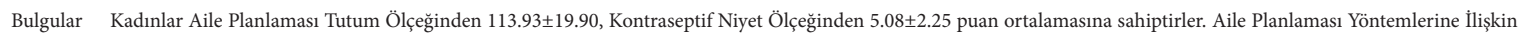
Tutum ile Kontraseptif Niyet Ölçeği toplam puan ortalaması arasında zayıf düzeyde istatistiksel olarak pozitif yönde anlamlı bir ilişki olduğu belirlenmiştir.

Sonuç Kadınların aile planlamasına yönelik tutumlarının orta düzeyde, kontraseptif yöntem kullanma niyetlerinin düșük düzeyde olduğu belirlenmiștir. Ayrıca kadınların aile planlamasına yönelik olumlu tutumları arttıkça, kontraseptif yöntem kullanma niyetlerinin de arttı̆̆ı saptanmıştır.

Anahta

Kelimeler

Aile planlaması; tutum; niyet

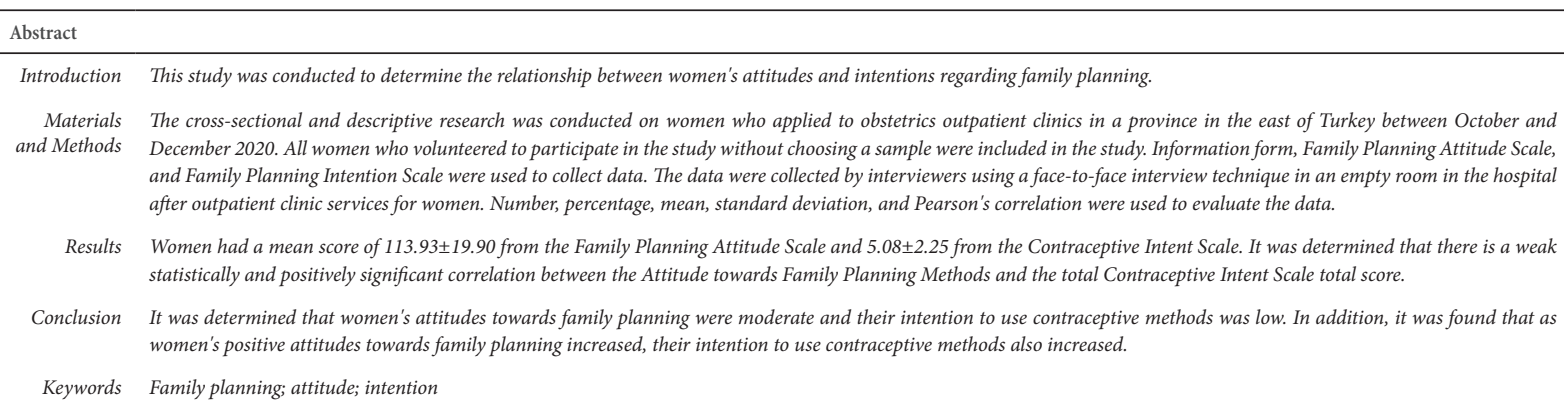




\section{GIIRIŞ}

Tüm kadınların, temel bir insan hakkı olarak, gebe kalıp kalmayacağına ve bunun zamanlamasını belirlemeye hakkı vardır. İstenmeyen gebelikler özelde anne ve bebek sağlığını genelde aile ve toplum sağlığını olumsuz yönde etkilediği için bir kadının ruhsal ve fiziksel açıdan kendisini gebeliğe hazır hissedeceği zamana kadar istenmeyen bir gebelikten etkili bir şekilde korunması kendisinin ve bebeğinin sağlığı için önem taşımaktadır. ${ }^{1,2}$ Dünya Sağlık Örgütü'nün verilerine göre son yıllarda kontraseptif kullanımındaki artışa rağmen bu konu hâlâ önemini korumaktadır. Dünya üzerinde birçok kadın artık çocuk sahibi olmak istemediği halde herhangi bir kontraseptif yöntem kullanmayan kadın oranı \%30 dur. ${ }^{3}$ Türkiye Nüfus ve Sağlık Araştırması (TNSA) 2018 verilerine göre, doğurganlık çağındaki kadınların \%63’ü başka çocuk istememekle birlikte kadınların \%30'u herhangi bir aile planlaması yöntemi kullanmamaktadır. Gebelikten korunma başarısı düşük olan geleneksel yöntemleri kullananların oranı ise \%26.1'dir. ${ }^{4}$ Yapılan çalışmalara göre, etkin aile planlaması yöntemi kullanmayı etkileyen faktörlerden biri kadının doğurganlığına ilişkin tutumu ve niyetidir. ${ }^{5-10}$ Tutumlar doğrudan gözlenemese de davranışları etkilediği bilinmektedir. Aile planlaması yöntemlerine yönelik tutumlar, yöntem kullanımını doğrudan etkilemektedir. Türk toplumunda genellikle doğurganlığın kadının statüsünü artırdığına inanılmakta ve bu nedenle kadınlar doğurganlıklarını sınırlandırmak istememektedir. ${ }^{11}$ Kadınların primer bakım hizmetlerinde rol alan başta ebeler olmak üzere hizmet sunan hekim ve hemşire aile planlaması eğitim ve danışmanlık hizmeti sunarken hizmet alanların yöntem seçimine yönelik tutumlarının bilinmesi, davranış değiştirme yönünde danışmanlık hizmetlerinin idame ettirilmesini sağlayacaktır. ${ }^{5}$ Aile planlaması yöntemlerinin kullanımını artırmak için yöntem kullanımını etkileyebileceği düşünülen faktörlerin belirlenmesi ve bu faktörleri kontrol etmeye yönelik planlamalar yapılması önemlidir. Kontraseptif davranış kullanılan kontraseptif yöntem seçimi ve yöntemin doğru kullanımı olarak tanımlanır. ${ }^{12}$ Teorik olarak, genelde insanın davranışları (ör. kontraseptif yönteme uyum sağlamak), o davranışa bağlı niyetin incelenmesi ile belirlenir. Niyetin temelini oluşturan faktörler ise kişinin belirli davranışlara ilişkin tutumu ve öznel normlarıdır. Tutum ve öznel normlar kişiden kişiye değişir. Bazı insanlar daha çok sosyal çevreden kaynaklanan subjektif normları bazıları da kendi tutum ve normlarına bağlı niyetleri önemsemektedir. ${ }^{13}$ Hortaçsu'nun aktardığg1na göre Ajzen ve Fishbein, insanların davranışlarının niyetlerinden tahmin edilebileceğini, tutumlarının ise niyetleri etkileyen iki öğeden birisi olduğunu savunmaktadır. ${ }^{14}$ Bireylerde kontraseptif kullanımında mevcut davranış ile kontraseptif niyet yakın ilişkidir. ${ }^{12}$ Ayrıca, kontraseptif yöntem kullanımıyla ilgili tutumlar ile kontraseptif niyet arasında önemli ilişki olduğu düşünülür. Akla dayalı davranış teorisine göre davranışsal niyet, kişisel davranışın en etkili tek öngörücüsü olduğuna göre ${ }^{15}$ kontraseptif niyet, kontraseptif yöntem uygulamasında anlamlı bir öngörücü olarak kullanılabilir. Gür'ün üreme çağındaki kadınların kontraseptif niyetlerini belirlemek amacıyla yaptığ çalışmasında ${ }^{16}$ kadınların kontraseptif niyetlerinin düşük olduğu; ideal çocuk sayısının artması, herhangi bir yöntem kullanılmaması, yöntem kullananların kondomu tercih etmesi ve hormonal kontraseptiflerin en etkili yöntem olarak düşünülmesinin kontraseptif niyeti azalttığg belirtilmiştir.

Aile planlaması hizmetini sunan ebeler tarafından kişinin hizmet alma ya da almama nedenleri ortaya çıkarılma$11,{ }^{2}$ kişinin bu konuya ait niyeti ve tutumu belirlenip aile planlamasına yönelik istendik davranışa ulaşması sağlanmalıdır. Hizmet alanların aile planlaması yöntemlerini seçerken tutumlarının bilinmesi, ebenin aile planlaması eğitimi ve danışmanlığı verirken, bireylerin tutumlarını göz önünde bulundurarak davranış değiștirme yönünde danışmanlık hizmetlerinin idame ettirilmesini sağlayacaktır. ${ }^{17}$ Aile planlaması hizmeti alanların gelecekte bu konu ile ilgili gereksinimleri konusunda plan yapabilmek için kontraseptif yöntem kullanma durumu ve eşlerin gelecekte yöntem kullanmaya ilişkin niyetleri ile ilgili danışanların ve danışmanların bilgilendirilmeye ihtiyaçları olduğu 
düşünülmektedir.

Bütün bunların ışı̆̆ı altında aile planlaması hizmetlerine ağırlık ve öncelik verilmesi önem taşımaktadır. Etkili aile planlaması hizmetlerinin sunumu için yöntemleri ve kullanımını etkileyen faktörlerin bilinmesi, yöntem kullanmaya yönelik niyet ve tutumun belirlenmesi gerekmektedir. ${ }^{7-10,18} \mathrm{Bu}$ nedenle ebeler hizmet sunduğu kitleye etkin ve kaliteli bakım sağlayabilmek için bireylerin öncelikle aile planlaması yöntemlerine yönelik genel danışmanlık yaparak eksik bilgilerini tamamlamalı ve yanlış bilgilerini düzeltmelidir. Şimdi ve gelecekteki aile planlaması yöntem kullanım niyetlerini ve tutumlarını belirleyerek yöntem/ yöntemlere özel danışmanlık hizmet içeriğini ve izlemlerini bu doğrultuda planlamalıdır.

Literatürde kadınların aile planlaması tutum ve niyetlerini aynı anda belirleyen ve karşılaştıran ölçek temelli sadece bir çalışmaya rastlanılmıştır. $\mathrm{Bu}$ nedenle ilgili literatüre katkı sağlayacağı düşünülerek bu araştırma evli kadınların aile planlamasına ilişkin tutumları ve niyetleri arasındaki ilişkinin belirlenmesi amacıyla yapılmıştır.

\section{GEREÇ ve YÖNTEM}

$\mathrm{Bu}$ araştırma kesitsel ve tanımlayıcı tiptedir. Araştırma Ekim-Aralık 2020 tarihleri arasında doğuda bir devlet hastanesinin kadın doğum polikliniklerine başvuran evli kadınlar üzerinde yapılmıştır. İlgili hastane, bölge hastanesi niteliğinde olması ve hasta yoğunluğu nedeniyle seçilmiştir. Hastane, bütün sosyo-ekonomik statüdeki kadınlara hizmet vermektedir.

Araştırma evrenini ilgili hastanenin kadın doğum polikliniklerine başvuran evli kadınlar oluşturmaktadır. Araştırmada örneklem seçimine gidilmeden belirtilen tarihlerde hastaneye başvuran ve çalışmaya katılmayı kabul eden kadınlar alınmıştır. Araştırmada evrenin bilinmemesi nedeniyle evrenin bilinmediği durumlarda kullanılan formülle örnekleme 383 kadın alınması planlanmıştır. Fakat Covid-19 pandemisi nedeniyle ancak 329 kadına ulaşılmıştır.
Verilerin toplanmasında araştırmacılar tarafından hazırlanan Tanıtıcı Bilgi Formu ile Aile Planlaması Tutum Ölçeği ve Kontraseptif Niyet Ölçeği kullanılmıştır.

Tanıtıcı Bilgi Formu, Araştırmacılar tarafından hazırlanan bilgi formu kadınların tanıtıcı özelliklerini sorgulayan (yaş, medeni durum, eğitim, yaşanılan yer vb) 16 sorudan oluşmuştur.

Aile Planlaması Tutum Ölçeği (APTÖ), Örsal ve Kubilay (2006) tarafından geliştirilmiştir. ${ }^{5}$ Ölçek likert tipi olup 34 maddeden oluşmaktadır. Ölçekteki her bir ifade 1'den 5'e kadar puanlanmaktadır. "Tamamen Katılıyorum yanıtı 1 puan ", "Katıllyorum 2 puan", "Kararsızım 3 puan”, "Katılmıyorum 4 puan”, “Tamamen Katılmiyorum 5 puan “ almaktadır. Ölçekte tersine kodlanması gereken ifade bulunmamaktadır. Ölçekten en az 34, en fazla 170 puan alınabilmektedir. Ölçek “Toplumun Aile Planlamasına İlişkin Tutumu”, "Aile Planlaması Yöntemlerine İlişkin Tutum” ve “Doğuma İlişkin Tutum” olmak üzere 3 alt boyuta sahiptir. Ölçeğin alt boyutlarından "Toplumun Aile Planlamasına İlişkin Tutumu"nu oluşturan madde sayısı 15'dir ve bu alt boyuttan en az 15 en fazla 75 puan alınabilir. Ölçeğin alt boyutlarından "Aile Planlaması Yöntemlerine İlişkin Tutumu"nu oluşturan madde sayısı 11'dir. Bu alt boyutundan en az 11 en fazla 55 puan alınabilir. Ölçeğin "Doğuma İlişkin Tutum" alt boyutunun madde sayıs 8'dir ve bu alt boyuttan en az 8 en fazla 40 puan alınabilir Ölçeğin Cronbach alfası $0.90,5$ bu çalışmada ise 0.92 olarak bulunmuştur.

Kontraseptif Niyet Ölçeği (KNÖ), Bennet ve Rocca tarafindan, kontraseptif niyetin değerlendirilmesi amacıyla, 2015 yılında geliştirilmiştir. ${ }^{12}$ Ölçeğin Türkçe geçerlik güvenirlik çalışması Suid ve Pasinlioğlu tarafından 2016 yılında yapılmıştır. ${ }^{19}$ Ölçek toplam 15 maddeden oluşmaktadır. Ölçek 4'lü likert tipindedir. Ölçeğin toplamından alınabilecek en düşük puan 0, en yüksek puan 15'tir. Puanın yükselmesi kontraseptif niyetin arttığını göstermektedir. Ölçeğin cronbach alfası $0.82,19$ bu çalışmada ise 0.79 olarak bulunmuştur. 
Veriler kadınlara poliklinik hizmetleri sonrası anketörler tarafından yüz yüze görüşme tekniği ile hastanedeki boş bir odada toplanmıştır. Veriler ortalama 10-15 dakikada toplanmıştır. Anketörler ebelik bilim dalında lisansüstü öğrencilerinden tercih edilmiştir. Bu araştırmada 2 anketör kullanılmıştır. Araştırmaya başlamadan önce anketörlere araştırmanın amacı ve veri toplamaya yönelik eğitim yapılmıştır. Anketörlerin, çalışmanın başında birkaç veri toplama deneyiminin gözetiminden sonra anketörler bu araştırmanın verilerini toplamıştır.

Verilerin analizi ve değerlendirilmesinde Statistical Package for the Social Sciences (SPSS) 22.0, paket programı kullanılarak analizler yapılmıştır. Bu çalışmada sayı, yüzde, ortalama, standart sapma, Pearson korelasyon analizi kullanılmıştır. Sonuçlar \%95'lik güven aralığında, anlamlılık $\mathrm{p}<0.05$ düzeyinde değerlendirilmiştir. Verilerin normal dağılım gösterip göstermediğini test etmek için Kolmogorov-Smirnov ve Shapiro-Wilk analizi kullanılmış ve verilerin normal dağılım gösterdiği saptanmıştır.

Çalışmaya başlamadan önce Atatürk Üniversitesi Sağlık Bilimleri Fakültesi Etik Kurulundan onay (21.05.2020 tarihli 20 sayı numaralı) alınmıştır. Daha sonra çalışmanın yapılacağı kurumdan resmi izin (13.07.2020) alınmıştır. Ayrıca çalışmaya katılan kadınlardan sözel onam alınmış ve çalışmanın her aşamasında Helsinki Deklerasyon Kurallarına uyulmuştur.

\section{BULGULAR}

Araştırma kapsamındaki kadınların sosyodemografik özellikleri Tablo 1'de verilmiştir. Kadınların \%35'inin üniversite mezunu, \%78.1'inin çalışmadı̆̆ı, \%51.7'sinin şehir merkezinde, \%82.7'sinin çekirdek ailede yaşad1ğ1, \%61.1'inin orta düzeyde gelir algısına sahip olduğu, \%92.1'inin sürekli bir ilaç kullanmadığı, \%85.4'ünün herhangi bir şeye karşı alerjisinin olmadığı, \%85.4'ünün sigara kullanmadığı, \%86.9'unun eşiyle akraba olmadığı, \%47.4'ünün eşi memur olarak çalıştığ 1 ve \%46.2'sinin eşinin üniversite mezunu olduğu belirlenmiştir. Kadınların \%82.5'inin birden fazla aile planlaması yöntemini (APY) bildiği, \%64.7’sinin APY kullanmadığı ve yöntem kullanan kadınların \%43.2'sinin hormonal yöntemleri tercih ettiği saptanmıştır.

\begin{tabular}{|c|c|c|}
\hline Özellikler & $\mathrm{n}$ & $\%$ \\
\hline $\begin{array}{l}\text { Eğitim durumu } \\
\text { İlkokul mezunu } \\
\text { Ortaokul mezunu } \\
\text { Lise mezunu } \\
\text { Üniversite ve üzeri }\end{array}$ & $\begin{array}{c}68 \\
75 \\
71 \\
115 \\
\end{array}$ & $\begin{array}{l}20.7 \\
22.8 \\
21.5 \\
35.0\end{array}$ \\
\hline $\begin{array}{l}\text { Çalışma durumu } \\
\text { Çalıșyor } \\
\text { Çalışmıyor }\end{array}$ & $\begin{array}{c}72 \\
257 \\
\end{array}$ & $\begin{array}{l}21.9 \\
78.1 \\
\end{array}$ \\
\hline $\begin{array}{l}\text { Yaşanılan yer } \\
\text { Şehir } \\
\text { İlçe } \\
\text { Köy }\end{array}$ & $\begin{array}{l}170 \\
96 \\
63 \\
\end{array}$ & $\begin{array}{l}51.7 \\
29.2 \\
19.1\end{array}$ \\
\hline $\begin{array}{l}\text { Aile tipi } \\
\text { Çekirdek } \\
\text { Geniş }\end{array}$ & $\begin{array}{c}272 \\
57\end{array}$ & $\begin{array}{l}82.7 \\
17.3\end{array}$ \\
\hline $\begin{array}{l}\text { Gelir durumu algisı } \\
\text { Kötü } \\
\text { Orta } \\
\text { İyi }\end{array}$ & $\begin{array}{c}63 \\
201 \\
65 \\
\end{array}$ & $\begin{array}{l}19.1 \\
61.1 \\
19.8 \\
\end{array}$ \\
\hline $\begin{array}{l}\text { Sürekli kullanılan bir ilaç varlı̆̆ı } \\
\text { Evet } \\
\text { Hayır }\end{array}$ & $\begin{array}{c}26 \\
303 \\
\end{array}$ & $\begin{array}{l}14.6 \\
85.4 \\
\end{array}$ \\
\hline $\begin{array}{l}\text { Sigara kullanma durumu } \\
\text { Kullanan } \\
\text { Kullanmayan }\end{array}$ & $\begin{array}{c}48 \\
281 \\
\end{array}$ & $\begin{array}{l}14.6 \\
85.4\end{array}$ \\
\hline $\begin{array}{l}\text { Eş ile akraba olma durumu } \\
\text { Evet } \\
\text { Hayır } \\
\end{array}$ & $\begin{array}{c}43 \\
286 \\
\end{array}$ & $\begin{array}{l}13.1 \\
86.9 \\
\end{array}$ \\
\hline $\begin{array}{l}\text { Eş meslek } \\
\text { Esnaf } \\
\text { Memur } \\
\text { Çiftçi } \\
\text { İşçi }\end{array}$ & $\begin{array}{c}74 \\
156 \\
58 \\
41\end{array}$ & $\begin{array}{l}22.5 \\
47.4 \\
17.6 \\
12.5\end{array}$ \\
\hline $\begin{array}{l}\text { Eş eğitim durumu } \\
\text { İlkokul mezunu } \\
\text { Ortaokul mezunu } \\
\text { Lise mezunu } \\
\text { Üniversite ve üzeri }\end{array}$ & $\begin{array}{c}42 \\
86 \\
49 \\
152 \\
\end{array}$ & $\begin{array}{l}12.8 \\
26.1 \\
14.9 \\
46.2\end{array}$ \\
\hline $\begin{array}{l}\text { Bilinen AP yöntemleri } \\
\text { Hormon içermeyen yöntemler } \\
\text { Hormon içeren yöntemler } \\
\text { Geleneksel yöntemler } \\
\text { Birden fazla yöntem } \\
\end{array}$ & $\begin{array}{c}17 \\
27 \\
14 \\
271\end{array}$ & $\begin{array}{c}5.1 \\
8.2 \\
4.2 \\
82.5\end{array}$ \\
\hline $\begin{array}{l}\text { APY kullanma durumu } \\
\text { Kullanan } \\
\text { Kullanmayan }\end{array}$ & $\begin{array}{l}116 \\
213\end{array}$ & $\begin{array}{l}35.3 \\
64.7\end{array}$ \\
\hline
\end{tabular}




\begin{tabular}{|l|c|c|}
\hline Kullanılan APY (n=116) & 33 & 28.4 \\
Hormon içermeyen yöntemler & 50 & 43.2 \\
Hormon içeren yöntemler & 33 & 28.4 \\
Geleneksel yöntemler & \multicolumn{2}{|c|}{ X \pm SS } \\
\hline \multicolumn{2}{|c|}{$30.48 \pm 6.10$} \\
\hline Yaş & $34.83 \pm 6.83$ \\
\hline Eş yaş & \multicolumn{2}{|c|}{ APY: Aile planlaması yöntemi, \pm SS: Ortalama ve Standart Sapma } \\
\hline
\end{tabular}

Kadınların, Aile Planlaması Tutum Ölçeği toplam ve alt boyutlarından ve Kontraseptif Niyet Ölçeği toplamından aldıkları puan ortalamaları Tablo 2'de gösterilmiştir. Kadınların Toplumun Aile Planlamasına İlişkin Tutumu alt boyut puan ortalamasının $46.82 \pm 12.91$ olduğu, Aile Planlaması Yöntemlerine İlişkin Tutum alt boyut puan

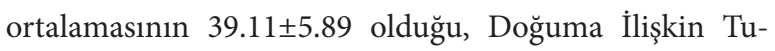
tum alt boyut puan ortalamasinın $27.99 \pm 4.93$ olduğu ve Aile Planlaması Tutum Ölçeği toplam puan ortalamasının $113.93 \pm 19.90$ olduğu belirlenmiştir. Kadınların Kontraseptif Niyet Ölçeği toplam puan ortalamasının 5.08 \pm 2.25 olduğu belirlenmiştir (Tablo 2).

Tablo 3'de APTÖ ile KNÖ puan ortalamaları arasındaki ilişki gösterilmiştir. Aile Planlaması Yöntemlerine İlişkin Tutum ile KNÖ toplam puan ortalamaları arasında zayıf düzeyde istatistiksel olarak pozitif yönde anlamlı bir ilişki olduğu belirlenmiştir ( $\mathrm{p}=0.010$ ) (Tablo 3).
Tablo 3. Kadınların APTÖ ve KNÖ puan ortalamaları arasındaki ilişki

\begin{tabular}{|c|c|c|c|}
\hline \multicolumn{3}{|c|}{ Ölçekler } & KNÖ \\
\hline \multirow{4}{*}{ АРТÖ } & $\begin{array}{l}\text { Toplumun Aile Planlamasına İlişkin } \\
\text { Tutumu }\end{array}$ & $\begin{array}{l}\mathrm{r} \\
\mathrm{p}\end{array}$ & $\begin{array}{l}0.025 \\
0.651\end{array}$ \\
\hline & $\begin{array}{l}\text { Aile Planlaması Yöntemlerine İlişkin } \\
\text { Tutum }\end{array}$ & $\begin{array}{l}\mathrm{r} \\
\mathrm{p}\end{array}$ & $\begin{array}{l}0.141 \\
0.010\end{array}$ \\
\hline & Doğuma İlişkin Tutum & $\begin{array}{l}\mathrm{r} \\
\mathrm{p}\end{array}$ & $\begin{array}{l}0.091 \\
0.101\end{array}$ \\
\hline & APTÖ Toplam & $\begin{array}{l}\mathrm{r} \\
\mathrm{p}\end{array}$ & $\begin{array}{l}0.080 \\
0.145\end{array}$ \\
\hline
\end{tabular}

APTÖ: Aile Planlaması Tutum Ölçeği, KNÖ: Kontraseptif Niyet Ölçeği

\section{TARTIŞMA}

Aile Planlaması Tutum Ölçeği ve Kontraseptif Niyet Ölçeklerinin toplamından ve alt boyutlarından alınabilecek en düşük, en yüksek puanlar ve ortanca doğrultusunda kadınların puan ortalamaları ilgili literatür ile tartışılmıştır. Kadınların aile planlamasına yönelik genel tutumlarının, toplumun aile planlamasına ilişkin tutumlarının, aile planlaması yöntemlerine ilişkin tutumlarının orta düzeyden biraz yüksek olduğu söylenebilir (Tablo 2). Önder'in Van'da yapmış olduğu çalışmada ölçek alt boyutlarının ve toplam puan ortalamalarının bu çalışma ile benzer olduğu saptanmıştır. ${ }^{9}$ Gözükara, Kabalcıŏlu, Ersin ${ }^{20}$ ile Ayaz ve Efe'nin ${ }^{7}$ yapmış oldukları çalışmalarda toplumun aile planlamasına ilişkin tutumları hariç diğer alt boyutlar ve toplam puan ortalaması bu çalışma ile benzerdir. Ayaz ve Efe'nin $^{7}$ çalışmasında kadınların aile planlamasına yönelik tutumlarının iyi düzeyde olduğu ifade edilmişken Gözükara, Kabalcıoğlu, Ersin çalışmasında ${ }^{20}$ kadınların aile planlamasına karşı tutumlarının istendik düzeyde olmadığg tespit etmiştir. Benzer şekilde, Apay, Nazik, Özdemir

\begin{tabular}{|c|c|c|c|c|}
\hline \multicolumn{2}{|l|}{ Ölçekler } & Minimum Puan & Maksimum Puan & $\mathrm{X} \pm \mathrm{SS}$ \\
\hline \multirow{4}{*}{ APTÖ Alt boyutlar } & Toplumun Aile Planlamasına İlişkin Tutumu & 15 & 75 & $46.82 \pm 12.91$ \\
\hline & Aile Planlaması Yöntemlerine İliş̧kin Tutum & 11 & 55 & $39.11 \pm 5.89$ \\
\hline & Doğuma İlişkin Tutum & 8 & 40 & $27.99 \pm 4.93$ \\
\hline & APTÖ Toplam & 44 & 170 & $113.93 \pm 19.90$ \\
\hline \multicolumn{2}{|l|}{ KNÖ Toplam } & 0 & 11 & $5.08 \pm 2.25$ \\
\hline
\end{tabular}


ve Pasinlioglu'nun Erzurum'da yürüttükleri çalışmada kadınların aile planlamasına karşı tutumlarının istendik düzeyde olmadığ lar ${ }^{18}$ çalışmasında ise ölçek alt boyutlarının ve toplam puan ortalamalarının çok daha düşük olduğu ve kadınların aile planlamasına karşı tutumlarının iyi olmadığı görülmüştür. Bu çalışmanın ve diğer çalışmaların çoğunluğunun ülkenin doğusunda yapılmış olması nedeni ile benzer sonuçların elde edildiği düşünülebilir. Aile planlaması tutumunun iyi düzeyde olumlu olmamasının, ilgili bölgede yaşayan kadınların AP yöntemlerine yönelik bilgi düzeylerinin düşük olmasından ve ataerkil yapının egemen olduğu toplumsal bir yapının etkin olmasından kaynaklandığı söylenebilir. Araştırma bulgusundan farklı olarak Tezel, Gönenç, Akgün, Öztaş ve Altuntaş ${ }^{10}$ çalışmasında ölçeğin tüm alt boyut ve toplam puan ortalamasının yüksek olduğu görülmüştür. Bu çalışmanın Ankara'da yapılmış olması bu farklılı̆̆ın sebebi olabilir.

\section{Kontraseptif Niyet Ölçeğinden kadınların kontraseptif} yöntem kullanma niyetlerinin düşük düzeyde olduğu söylenebilir (Tablo 2). Benzer şekilde Öner'in çalışmasında ${ }^{9}$ ve Gür'ün çalışmasında ${ }^{16}$ kadınların kontraseptif yöntem kullanma niyetlerinin düşük olduğu belirlenmiştir. Suid çalışmasında ${ }^{19}$ ise kadınların kontraseptif niyetlerinin orta düzeyde olduğu bulunmuştur. TNSA (2018) raporunda evli olan ve herhangi bir yöntem kullanmayan kadınların yarısından fazlasının gelecekte de bir yöntem kullanma niyetinde olmadıkları bildirilmiştir. ${ }^{4}$ Araştırmada yer alan kadınların yaş ortalamasının ideal çocuk doğurma aralığında olması, obstetrik özelliklerine bakıldığında büyük çoğunluğunun henüz düşünülen ideal çocuk sayısına ulaşmadığı, yöntem kullananların kullandığı yöntemden memnun olmaması, yöntemler hakkında detaylı bilgiye sahip olmaması gibi nedenler kontraseptif niyetin düşük olmasını etkilemiş olabilir ${ }^{16}$ Benzer şekilde Gür'ün çalışmasında ${ }^{16}$ da herhangi bir yöntem kullanılmaması, yöntem kullananların kondomu tercih etmesi ve hormonal kontraseptiflerin en etkili yöntem olarak düşünülmesinin kontraseptif niyeti azaltığı bulunmuştur. Kadınların kont- raseptif yöntem kullanma niyetlerinin düşük olmasının bir başka nedeni de dini ve kültürel boyuttur. Eş ve aile büyüklerinin kadının yöntem kullanmasına izin vermemesi, kadınların yöntem kullanmanın günah olduğunu düşünmesi de yöntem kullanım niyetini etkilemiş olabilir. Kadınların aile planlamasına ilişkin tutumları ile kontraseptif yöntem kullanma niyetleri arasındaki ilişki incelendiğinde kadınların aile planlaması yöntemlerine yönelik olumlu tutumları arttıkça kontraseptif yöntem kullanma niyetlerinin de arttığı görülmektedir (Tablo 3). Araştırma bulgusuna benzer şekilde Öner'in çalışmasında ${ }^{9}$ da kadınların aile planlamasına yönelik olumlu tutumları arttıkça, kontraseptif yöntem kullanma niyetlerinin de arttığ1 tespit edilmiştir. Kadınların sosyal yaşamlarını sürdürürken aynı zamanda çocuk bakımını da üstlenmeleri ve yaşamda karşılaşılan zorluklar kadınların aile planlamasına olumlu bir bakış açısı geliştirmelerini sağlamıştır. Buna paralel olarak da kontraseptif yöntemlere ilişkin bilgi edinme ve güvenilirliğine göre tercih etme söz konusudur.

$\mathrm{Bu}$ araştırma sonucunda kadınların aile planlamasına yönelik tutumları orta düzeyde iyi, kontraseptif yöntem kullanma niyetleri düşük düzeydedir. Kadınların aile planlamasına yönelik olumlu tutumları arttıkça kontraseptif yöntem kullanma niyetleri de artmaktadır.

$\mathrm{Bu}$ sonuçlar doğrultusunda, aile planlamasının önemi hakkında etkin ve kaliteli danışmanlık ve eğitimlerin yapılması önerilebilir. Sunulacak hizmetler ile bireylerin kendisine en uygun ve etkin aile planlaması yöntemi seçebilmesine yardımcı olunarak yöntem kabulünü, memnuniyeti ve kullanım süresi artırılabilir. Bu da başarılı kullanım oranının artmasına istemeyen ve riskli gebeliklerin önlenmesine, anne-bebek sağlığı açısından risklerin minimalize edilmesine katkı sağlayacaktır. Öncelikle genel ve sonrasında yönteme özgü özel danışmanlıkların yapılması ile kadınların aile planlamasına yönelik tutumlarının belirlenmesi varsa aile planlamasına ilişkin yanlış tutumları düzeltilebilir. Ayrıca kadınların kontraseptif niyetleri ve yöntem kullanım niyetini etkileyen faktörler de kolay- 
lıkla belirlenebilir. Elde edilen sonuçlar doğrultusunda da kontraseptif niyetin arttırılmasını sağlayacak bireye özgü uygun girişimler planlanabilir.

\section{Etik Kurul Onayı}

Atatürk Üniversitesi Sağlık Bilimleri Fakültesi Etik Kurulundan 21.05.2020 tarihli 20 sayı numaralı etik kurul onayı alınmıştır. 
Sakarya Tip Dergisi 2021;11(4):743-750

EJDER TEKGÜNDÜZ ve Ark., Evli Kadınların Aile Ilişskinin Planlaması Tutum Ve Niyetleri

\section{References}

1. Memmel L, Gilliam M. Kontrasepsiyon. Ayhan A. Tașkuran Ç. Dursun P, çeviri editörleri. Danforth's Obstetrik ve Jinekoloji.10. Baskı. Ankara: Güneș Tip Kitabevleri, 2010. s:567-585.

2. Ulusal Aile Planlaması Hizmet Rehberi, T.C. Sağlık Bakanlığı Ana Çocuk Sağlı̆̆ı ve Aile Planlaması Genel Müdürlü̆g̈ü Ankara, 2005

3. World Family Planning Report 2017. https://www.un.org/development/desa/pd/sites/www. un.org.development.desa.pd/files/files/documents/2020/Jan/un_2017_worldfamilyplanning_highlights.pdf Erişim Tarihi: 08.12.2020

4. Türkiye Nüfus ve Sağllk Araştırma Raporu 2018. http://www.hips.hacettepe.edu.tr/ tnsa2018/rapor/TNSA2018_ana_Rapor.pdf Erișim Tarihi: 10.12.2020

5. Örsal Ö, Kubilay G. Aile planlaması tutum ölçeği geliștirilmesi. İstanbul Üniversitesi Florence Ninhtingale Hemşirelik Yüksekokulu Dergisi 2007;15(60):155-164.

6. Onwuzunrike BK, Uzochukwu BSC. Knowledge, attitude and practice of amongst women in a high density low-income urban of Enugu, Nigeria. African Journal Reproductive Health 2001;5(2):83-89

7. Ayaz S, Efe C. Family planning attitudes of women and affecting factors. Journal of The Turkish-German Gynecological Association 2009;10(3):137-141.

8. Apay E, Nazik E, Özdemir F, Pasinlioglu T. Kadınların aile planlamasına ilișkin tutumlartnin belirlenmesi. Anadolu Hemșirelik ve Saglk Bilimleri Dergisi 2010; 13(3):39-45.

9. Öner O. Evli Kadınların Doğurganlı̆̆a ve Aile Planlamasına Yönelik Tutumları ile Kontraseptif Yöntem Kullanma Niyetleri Arasındaki Illişkinin ve Etkileyen Faktörlerin Belirlenmesi Yüksek Lisans Tezi, Atatürk Üniversitesi Sağlık Bilimleri Enstitüsü Doğum Kadın Sağllğı ve Hemşireliği Anabilim Dal, Erzurum.2019

10. Tezel A, Gönenç İM, Akgün Ş, Öztaş KD, Altuntaş YT. Kadınların aile planlamasina yönelik tutumları ve etkileyen faktörler, Anadolu Hemșirelik ve Sağltk Bilimleri Dergisi, 2015, 18(3): 181-188.
11. Özbay F. Kadının statüsü ve doğurganlık. Arat N, editör. Türkiye’de Kadın Olgusu. İstanbul: Say Yayinlarl; 1992. s:147-165.

12. Bennett TRR, Rocca CH. Development of a brief questionnaire to assess contraceptive intent. Education and Counseling, 2015; 98:1425-1430.

13. Lee J, Carvallo M, Lee T. Psychometric properties of a measure assessing attitudes and norms as determinants of intention to use oral contraceptives. Asian Nursing Research, 2015,9:138-145

14. Hortaçsu N. En Güzel Psikoloji Sosyal Psikoloji, 1. Baskı. Ankara: İmge Kitabevi; 2012. s. 295-303.

15. Wang RH, Hsu MT, Wang HH. Potential factors associated with contraceptive intention among adolescent males in Taiwan. Kaohsiung Journal Medical Sciences, 2004, 20:115-123.

16. Gür EY. Üreme çağındaki kadınların kontraseptif niyetlerinin belirlenmesi. 1. Uluslararası Anadolu Ebeler Derneği Kongresi (online) 20-22 Kastm 2020 s.83-89.

17. Saygıl P. Aile planlaması hizmetlerinde hemșirenin rolü. Turkiye Klinikleri J Surg Med Sci. 2006;2(13):37-44.

18. Çetişli Egelioğlu N, Kahveci M, Ișık S, Hacılar A. Kadınların postpartum kontraseptiftercihleri ve tutumları. JAREN 2020;6(1):67-72.

19. Suid NR. Kontraseptif Niyet Ölçeğinin Geçerlilik ve Güvenilirlik Çalışması. Sağlk Bilimleri Enstitüsü, Doğum Kadın Sağllğı ve Hastalıkları Hemșirelĭğ Anabilimdalı. Yüksek Lisans Tezi, Erzurum: Atatürk Üniversitesi, 2016.

20. Gözükara F, Kabalcıŏ̆lu F, Ersin F. Șanlıurfa ilinde kadınların aile planlamasına ilişkin tutumlarmin belirlenmesi, Harran Universitesi, Tip Fakültesi Dergisi, 2015, 1(12): 9-16. 